BULLETIN Bulletin hispanique

HispaniQuE Université Michel de Montaigne Bordeaux

113-1| 2011

Actes de 2 colloques

\title{
«Licencia de imprimir damos»
}

libros y avatares en la difusión de la poesía novohispana (1675-1710)

\section{Ángel Estévez Molinero}

\section{(2) OpenEdition}

Journals

Edición electrónica

URL: http://journals.openedition.org/bulletinhispanique/1311

DOI: 10.4000/bulletinhispanique.1311

ISSN: 1775-3821

Editor

Presses universitaires de Bordeaux

\section{Edición impresa}

Fecha de publicación: 1 junio 2011

Paginación: 43-67

ISBN: 978-2-86781-740-3

ISSN: 0007-4640

Referencia electrónica

Ángel Estévez Molinero, « «Licencia de imprimir damos» », Bulletin hispanique [En línea], 113-1 | 2011,

Publicado el 01 junio 2014, consultado el 06 mayo 2019. URL : http://journals.openedition.org/

bulletinhispanique/1311; DOI : 10.4000/bulletinhispanique.1311 


\title{
«Licencia de imprimir damos»: libros y avatares en la difusión de la poesía novohispana (1675-1710)
}

\author{
Ángel Estévez Molinero \\ Universidad de Córdoba
}

Cet article propose l'analyse de sept livres de poésie de la Nouvelle Espagne situés chronologiquement entre le Ramillete de varias flores poéticas (1675) de Jacinto de Evia et la Flor de Academias (1710); entre ces deux auvres se situent le Triunfo Parténico de Sigüenza y Góngora, le Diente del Parnaso de Caviedes, et les euvres de sor Juana: Inundación castálida, Segundo volumen et Fama y obras póstumas. L'étude concerne les divers contextes de production, ainsi que la diffusion des textes imprimés ou manuscrits et leur inégale influence dans l'espace et le temps, avec une attention particulière accordée aux ouvres de sor Juana Inés de la Cruz et de Valle y Caviedes.

El presente artículo se centra en el estudio de siete libros de poesía novohispana, enmarcados cronológicamente entre el Ramillete de varias flores poéticas (1675) de Jacinto de Evia y la Flor de Academias (1710); en medio se encuentran el Triunfo Parténico de Sigüenza y Góngora, el Diente del Parnaso de Caviedes y las obras de sor Juana: Inundación castálida, Segundo volumen y Fama y obras póstumas. Se atiende a las distintas circunstancias en que surgen, a su difusión manuscrita o impresa y a su desigual proyección en el espacio y en el tiempo, prestando atención especial a las obras de sor Juana Inés de la Cruz y Valle y Caviedes.

The present paper focuses on the study of seven books of Novohispanic Poetry, chronologically framed between Jacinto de Evia's Ramillete de varias flores poéticas (1675) and Flor de Academias (1710); between those works, we find Sigüenza y Gongora's Triunfo Parténico, Caviedes's Diente del Parnaso and sor Juana's work Inundación castálida, Segundo volumen and Fama y obras póstumas. This study

Bulletin Hispanique, Tome 113, nº 1 - juin 2011 - p. 43 à 67. 
also investigates the different circumstances in which they were created, the print or manuscript diffusion and their uneven projection in space and time, paying special attention to the works of sor Juana Inés de la Cruz and Valle y Caviedes.

Mots-clés: Poésie - Nouvelle Espagne - diffusion - imprimé - manuscrit.

$\mathrm{E}$ N el anchuroso espacio de la colonia, básicamente limitado en la práctica de la impresión a México y Lima, el estado de la difusión poética propia (es decir, novohispana) se antoja en buena medida desolador; más aún en el caso de la difusión impresa. Bien podría trasladarse a la escasez de infraestructuras para ello y a la presión ideológica en la elección de los productos, el lamento, entreverado de acusadora ironía, que destila Espinosa Medrano en su Apologético cuando manifiesta (valga la conjunción paronomásica de empresa/impresa): "Tarde me parece que salgo a esta empresa; pero vivimos muy lejos los criollos y, si no traen las alas del interés, perezosamente nos visitan las cosas de España» ${ }^{1}$. Los hechos así lo certifican ${ }^{2}$. En efecto, de las siete obras que serán objeto de atención, dos permanecerán secularmente manuscritas (la de Caviedes y la Flor de Academias); de las cinco que se publican, una ve la luz en México (Triunfo Parténico, de Sigüenza y Góngora), tres en Madrid (Ramillete de varias flores poéticas, de Jacinto de Evia, Inundación castálida y Fama y obras póstumas de sor Juana Inés de la Cruz) y la restante en Sevilla (Segundo volumen, también de la monja jerónima).

Ateniéndonos a la itinerancia cronológica del periodo acotado, se publica en 1675, después de un paréntesis de varias décadas sin que se edite ninguna obra relevante de poesía novohispana en la metrópolis o en la colonia, el Ramillete de varias flores poéticas de Jacinto de Evia, que «es obra fundamental para conocer la expansión de la lírica áurea peninsular en las ya no tan nuevas

1. Juan de Espinosa Medrano, Apologético a favor de Don Luis de Góngora, ed. José Carlos González Boixo, Roma, Bulzoni, 1997, p. 41.

2. Una aproximación panorámica al respecto puedeverse en Ángel Estévez, «La conformación del canon en la poesía hispanoamericana del siglo XVII», en Begoña López Bueno (dir.), El canon poético en el siglo XVII, Sevilla, Secretariado de Publicaciones de la Universidad de Sevilla, 2010, pp. 475-497, y «Señas de identidad de la poesía hispanoamericana en el siglo XVII», en Ignacio García Aguilar (ed.), Tras el canon: La poesía del Barroco tardío, Vigo, Academia del Hispanismo, 2009, pp. 127-142, así como Pedro Ruiz Pérez, "Crónica y celebración de los ingenios novohispanos», en Guillermo Serés y Mercedes Serna (eds.), Los límites del Océano. Estudios filológicos de crónica y época, Bellaterra, Centro para la Edición de los Clásicos Españoles/Universidad Autónoma de Barcelona, 2009, pp. 207-235. 
fronteras americanas» $\mathrm{y}$ "piedra fundamental para el mejor entendimiento de la poesía que se escribe en Hispanoamérica a partir de su fecha de publicación", como indican certeramente Labrador y DiFranco en la "Nota editorial" a su reciente edición ${ }^{3}$; no obstante, crítica e historiográficamente el Ramillete no pasó de ser un mero «referente referido, y así anduvo de boca en boca sin que nadie se hubiese preocupado de desempolvarlo de algún anaquel particular o conventual», según advierte Rodrigo Pesántez ${ }^{4}$. En su conformación material reproduce "una instancia autorial de ordenación», por decirlo con palabras de Begońa López Bueno ${ }^{5}$, claramente observable desde los paratextos y, tras ellos, en la macroestructura textual. Aquéllos acompañan la dedicatoria, la aprobación, la tasa y la fe de erratas con la licencia del Ordinario, una segunda de fray Felipe Colombo y una tercera de los Señores del Consejo que, junto al prólogo dirigido $A$ la juventud estudiosa, facilitan inequívocas direcciones de lectura e interpretación ${ }^{6}$. El macrotexto, por su parte, se organiza en cuatro grandes bloques, precedido cada uno de ellos por un prólogo: 1/ Flores fúnebres, 2/ Flores heroicas y líricas, 3/ Flores amorosas y 4/ Flores burlescas y satíricas, copando la presencia casi en exclusiva el padre Bastidas y el propio Evia. Se añaden, en un quinto apartado, Otras flores, aunque pocas [cinco composiciones], del culto ingenio y floridísimo poeta, el Doctor D. Hernando Dominguez Camargo, cuya inclusión se explica porque «cuanta es mayor la variedad de las flores, tanto más vistoso sale el ramillete que de ellas se compone, y mejor logran los ojos el desvelo de su atención y el buen gusto de su curiosidad» ${ }^{7}$, según aclara Evia en la introducción a este bloque. El Ramillete se completa con las prosas tediosas de las Flores de certámenes y las de oraciones, y se cierra con la Invectiva apologética, con dedicatoria y prólogo de Evia Al curioso lector, seguido de sendos romances a la pasión de Cristo de Domínguez Camargo y de Paravicino, y de los preliminares paródicos, con incisivo tono crítico, del bogotano (dedicatoria,

3. José J. Labrador Herráiz y Ralph A. DiFranco, en «Nota editorial» a Xacinto de Evia, Ramillete de varias flores poéticas, con estudio de Rodrigo Pesántez Rodas, México, Frente de Afirmación Hispanista, A.C., 2009, p. 39.

4. Rodrigo Pesántez Rodas, en su estudio a Xacinto de Evia, Ramillete de varias flores poéticas, ed. José J. Labrador y Ralph A. DiFranco, op. cit., p. 34.

5. Begoña López Bueno, «Problemas específicos de la edición de textos poéticos: la ordenación del corpus», Criticón, 83, 2001, pp. 147-164 (152).

6. Sobre la importancia de los paratextos en el marco institucional y en un horizonte pragmático, véase Ignacio García Aguilar, Poesía y edición en el Siglo de Oro, Madrid, Calambur, 2009.

7. Xacinto de Evia, Ramillete de varias flores poéticas, Madrid, Nicolás Xamares, 1675, p. 235, en Antonio Lorente Medina (ed.), Textos clásicos de poesía virreinal, Madrid, Colección Clásicos Tavera, 2001 [CD-rom]. 
razonamiento al lector, fe de erratas, aprobación e introducción a la Obra) que anteceden, orientando la lectura, a la Invectiva propiamente dicha.

En el trayecto del autor-recopilador a la impresión, estamos ante el caso de un libro dentro de otro libro al decidirse la inclusión de la Invectiva (unas 100 páginas en el total de 406) en el conjunto de las flores para hacer más vistosa la variedad del ramillete, reconduciendo la primera intención que fue la de publicar en dos tomos distintos el Ramillete y la Invectiva. En efecto, como recuerda Rodrigo Pesántez ${ }^{8}$, Antonio Bastidas facilitó a Evia la Invectiva para que la incluyera en la parte final del Ramillete; cambia luego de opinión y, al enviar a Madrid el dinero para la edición, le indica al padre Bermudo que 200 patacones son para el Ramillete y 100 para la Invectiva; como es fácil inferir, la petición se incumplió (posiblemente para acelerar la impresión o acaso para abaratar costes; o, sencillamente, se retomó la idea inicial). Ese plan de edición separada justificaría los preliminares antes mencionados de Jacinto de Evia. En cualquier caso, la varietas refrenda la entidad del libro en cuanto agrupamiento organizado de textos, pragmáticamente destinados al ámbito jesuítico o, en todo caso, a círculos reducidos, pues se trata de una "poesía escrita más para ellos y para lectores cultos que para el pueblo, menos preparado" como ponen de manifiesto las abundantes "citas bíblicas, citas de los Santos Padres, citas y alusiones a obras peninsulares, citas de teólogos y tratadistas [que] se entretejen con otras de los clásicos, con neologismos, con páginas y páginas en insufrible prosa latina», según indican Labrador y DiFranco'. El Ramillete es, pues, un libro impreso, publicado en España, circunscrito en su difusión inmediata a un ámbito culto y recluido hasta fechas no lejanas en el silencio de los anaqueles a pesar de su interés historiográfico.

Ocho años después de esta primera antología novohispana impresa, en 1683, se publica en México el Triunfo Parténico de Carlos Sigüenza y Góngora, quien refiere los certámenes celebrados en honor de la Inmaculada Concepción y recopila, entre prosas plomizas ${ }^{10}$, las composiciones premiadas entre las más de quinientas recibidas, así como los epigramas que el propio Sigüenza va regalando, con pretensiones ingeniosas, a cada uno de los

8. Cfr. Rodrigo Pesántez en su estudio a Xacinto de Evia, op. cit., p. 17 y ss.

9. José J. Labrador y Ralph A. DiFranco, en "Nota editorial" a Xacinto de Evia, op. cit., pp. 39-40.

10. En lo que concierne a la prosa, se trata de «un libro tedioso como pocos», según Antonio Carreira, «Pros y contras de la influencia gongorina en el Triunfo Parténico (1683) de Sigüenza y Góngora», en Marc Vitse (ed.), Homenaje a Henri Guerreiro. La hagiografía entre historia y literatura en la Edad Media y el Siglo de Oro, Madrid, Vervuert, 2005, pp. 347-364 (347). 
premiados. El libro se urde en el contexto de un «espíritu acendradamente católico», según Rojas Garcidueñas ${ }^{11}$, y de una marcada devoción a la Virgen por inmaculadamente concebida, al calor de las fiestas que celebró en su honor la ciudad de México entre 1682 y 1683, a las que se une la Pontificia, Imperial y Regia Academia Mexicana, constituyendo su publicación la traca final de dichos fastos. El título es, al respecto, suficientemente explícito: Triumpho Parthénico, que en glorias de Maria Santissima inmaculadamente concebida, celebró la Pontificia, Imperial, y Regia Academia Mexicana... Describelo Don Carlos Sigüenza y Góngora Mexicano, y en ella Cathedrático proprietario de Mathemáticas; y, a pie de portada, Juan de Rivera, en el Empedradillo, 1683. Prisas se dieron las prensas para acoger con sorprendente celeridad la tediosa descripción de las celebraciones, la relación, términos, premios y premiados en los certámenes, y las composiciones premiadas, enmaquetadas según la rígida ordenación de las actas de academias; pero, claro, las prisas se entienden: el Triunfo Parténico (sintagma destacado en portada con el cuerpo de letra mayor) era la contribución con que toda una Pontificia, Imperial y Regia Academia Mexicana se unía a las celebraciones en glorias de María (cuerpo de letra más pequeño) que, además, describía el sabio D. Carlos Sigüenza y Góngora (cuerpo de letra similar al anterior y en cursiva). Pero Sigüenza, aun condicionado por el formato propio de las academias, no se limita a describir, sino que, como indica en la Prevención a quien leyere, tuvo por lisonja "la obediencia que se me impuso para formar este libro..." [la cursiva es nuestra].

Otros elementos paratextuales ayudan a entender lo que decimos. Así, tras la portada, el folio $2 \mathrm{r}$ lo ocupan íntegramente el nombre y títulos del destinatario: Al Exmo. Señor D. Tomás Antonio Lorenzo Manrique de la Cerda, Enríquez Afán de Ribera, Portocarrero y Cárdenas, Conde de Paredes, Marqués de la Laguna, Comendador de..., etc., todo simétricamente enmarcado en cinco niveles decrecientes con las letras todas ellas mayúsculas. Sigue a la dedicatoria, firmada por Sigüenza, la aprobación del M.R.P. Francisco de Florencia, quien, al refererise a la «arquitectura deste volumen» (y repárese que el libro es otra de las arquitecturas montadas para la ocasión) destaca que su «acertada disposición» se debe a D. Carlos de Sigüenza y Góngora (f. IVv). En la misma onda, una segunda aprobación de D. Francisco de Aguilar insiste en "no censurar, sino aplaudir y admirar las luces de elocuencia con que el autor (Sigüenza) nos muestra las deste Triunfo» (f. Vv). En la suma de las licencias, la de don Diego José de Bustos se concede el 22 de marzo de

11. José Rojas Garcidueñas (ed.), introducción a Carlos Sigüenza y Góngora, Triunfo Parténico, México, Xochitl, 1945, p. 10. 
1683, y la de Bernardino de Amezaga, el 6 de abril de ese año. Una breve Prevención a quien leyere, con indicación de las erratas en la misma página y cuatro sonetos que encumbran a Sigüenza como "Góngora segundo», dan paso al macrotexto, impreso en letra cómodamente legible, pero escrito con prosa tan plomiza y tediosa que desalienta al lector más esforzado. El libro, como puede deducirse, se había gestado en un ambiente ideológica y socialmente muy favorable y, por lo mismo, se materializó de inmediato como tal, gracias además al "poderoso influjo» (f. Vr), según precisa Francisco de Aguilar, de D. Juan Narváez, rector a la sazón de la Academia Mexicana, al padrinazgo del Marqués de la Laguna y a la bendición de altos cargos eclesiásticos. Desde su gestación durante los dos certámenes celebrados entre 1682 y 1683 hasta su desenlace en entidad material, con licencias para imprimir en marzo y abril, el libro tiene algo de parto prematuro, no tanto en su presentación externa cuanto en los textos internamente representados, pues, este sentido, como agudamente apreció Antonio Carreira, «de su lectura se infiere que no fue el asunto celebrado, sino el relumbre social y el valor de los premios, lo que pudo mover a los cisnes mexicanos, incluido el propio Sigüenza, a hacer lo único que estaba a su alcance, que es adoptar las citas y maneras del modelo remoto [en referencia Góngora] sin la menor motivación interna» ${ }^{12}$.

Caso muy distinto, en esto de la motivación, es el de otra mexicana, Musa décima, Sor Juana Inés de la Cruz. No se trata ahora de insistir en las excelencias de su poesía, por más que no sobre recordar que fue quien mejor asimiló y aprovechó la herencia gongorina en todo el ámbito hispánico. Se trata de observar su producción en ese trayecto que discurre de la autora al libro, un trayecto que ella apenas recorre y que, acaso por ello, ofrece un recorrido con no pocos interrogantes. Queda al margen el éxito editorial, espectacularmente indiscutible, que la obra tuvo en vida de su autora (dos ediciones y seis reediciones) y post mortem (una edición y once reediciones hasta 1725), al alcance de poquísimos autores del Barroco. Vamos a centrar la atención en los aspectos pragmáticos que se aprecian en cada uno de los libros (Inundación castálida, Segundo volumen y la Fama) considerados como entidad material y como agrupación de un conjunto de textos que presentan una organización determinada. Una simple ojeada a los paratextos y, de entrada, a las portadas de esas tres ediciones llama de inmediato la atención sobre los cambios producidos a cualquier lector medianamente atento. En efecto, la apoteosis barroca concentrada en el título de la primera edición, Inundación castálida [1689], se remansa sucesivamente en Poemas (reediciones

12. Antonio Carreira, op. cit., pp. 362-63. 
de Madrid, Barcelona y Zaragoza) ${ }^{13}$ y se resuelve solo tres años después [1692] en un título tan austero como Segundo volumen, de cuya portada se retiran los laureles de única poetisa, Musa décima y tan solo se destaca su condición de monja; y se quita también, antojándose pragmáticamente atractiva para el lector, cualquier indicación (a manera de la que lucía en Inundación castálida o en las sucesivas reediciones de Poemas) de que la autora en varios metros, idiomas y estilos fertiliza varios asuntos con elegantes, sutiles, claros, ingeniosos y útiles versos para enseñanza, recreo y admiración. Como puede apreciarse sin salir de la portada, la gradación significativa de los títulos (Inundación castálida, Poemas, Segundo volumen) y los otros cambios operados resultan ciertamente llamativos.

Cuando, tras la portada, se cotejan los elementos paratextuales, se descubren curiosas descompensaciones. En la princeps encontramos un romance heroico de José Pérez de Montoro y un soneto de Dońa Catalina de Alfaro, la aprobación de fray Luis Tineo, la licencia del Ordinario, una nueva aprobación del P. Calleja, la suma del privilegio, la fe de erratas, la suma de la tasa, el prólogo al lector (en prosa y sin firma, sustituido a partir de 1690 por un prólogo en verso de la propia autora) y un soneto de Sor Juana a la condesa de Paredes «enviándole estos papeles». Los trámites no llegan a los tres meses: del 28 de agosto al 19 de noviembre de 1689. Teniendo en cuenta la categoría social de la mecenas y la fama de la autora, todo está dentro de los usos y plazos ya vistos en el Triunfo Parténico (dedicado al conde de Paredes), salvo, para ser precisos, la anteposición de los poemas laudatorios al resto de elementos paratextuales. Pero lo del Segundo volumen, y más por contraste con lo visto, no parece tan normal; tras la dedicatoria a Don Juan de Orúe, viene la primera censura (en Sevilla a 18 de julio de 1691) y la correspondiente licencia (el 28 de ese mes), una segunda censura (el 15 de julio) y la consiguiente licencia (18 de julio); a continuación, una nota de D. Juan de Orúe pidiendo el apoyo de «algunos varones insignes en religión», petición a la que acuden siete religiosos de distintas órdenes que derraman sus discursos panegíricos a lo largo de 44 páginas; los elogios prosiguen con diez composiciones (una de ellas en latín); tras todo ello, y acaso por ello, llega la aprobación definitiva, fechada en Madrid el 16 de mayo de 1692

13. Facilitando en lo que al título concierne una discreta transición hacia el Segundo volumen, como si el desbordamiento de la fuente Castalia hubiera dado ya sus frutos, en estas reediciones se obvia la causa y se destacan los efectos de la inundación: Poemas. Poco más cambia en las reediciones, salvo la especificación de poetisa americana y el destinatario (que en la de Madrid, 1690, sigue siendo la condesa de Paredes, como en Inundación), así como noticias de la impresión y la supresión de un pequeño pero significativo párrafo, como se verá más adelante, en la aprobación de Fr. Luis Tineo. 
(unos diez meses después de la primera), sentenciada por la licencia real, en Aranjuez, el 20 de mayo, con la fe de erratas (22 de mayo) y la tasa (23 de dicho mes). Y llegamos así hasta la página cien con los preliminares.

¿Qué ha ocurrido entre 1689 y 1692 para que el viaje del texto al libro se antoje tan dilatado (y posiblemente accidentado) como dan a entender los paratextos? Sin olvidar la categoría y celebridad intelectual y literaria de la autora para congregar tanta pluma (como ocurrirá años después con la Fama), lo ocurrido, creemos, se debe a una sistemática interacción del marco histórico-cultural, las implicaciones paratextuales e intertextuales y los textos. La cuestión es espinosa, pero, sin pretender sobrepasar los límites de la especulación (no es tal el objeto de este análisis), vale la pena suscitarla en el ámbito de un horizonte abierto. En 1690, en México, imprenta de la viuda de Bernardo Calderón, el Dr. Ambrosio de Lima hace público el Auto sacramental del divino Narciso, precedido de una loa, con todo lo que conlleva el hecho de que una mujer, y monja, se dedique a escribir teatro ${ }^{14}$ y que incorpore, desde la loa que portica el Auto sacramental, elementos y personajes alegóricos autóctonos que solían animar las fiestas de la plaza pública, lo que no debió agradar a los inquisidores del Santo Oficio y en particular al arzobispo Aguiar y Seijas ${ }^{15}$. Ese mismo año, a fines de noviembre, se publica, sin el conocimiento de Sor Juana, la Carta Atenagórica, incluida luego en el Segundo volumen de sus obras con el título de Crisis de un sermón, que dio lugar a la Carta de sor Filotea de la Cruz (bajo cuyo nombre se ocultaba el obispo de Puebla, Manuel Fernández de Santa Cruz), fechada

14. Es suficientemente explícito el juicio siguiente de Guillermo Schmidhuber, «Sor Juana Inés de la Cruz, dramaturga» [en línea], Sincronía, primavera 2001, http://www. dartmouth. edu/_sorjuana/Comentaries/Schmidhuber/Schmidhuber.htm, p. 6, al escribir: "Cuatro son los campos en los que sor Juana impuso una diferente forma de ser mujer: como ser humano exigió su derecho a la educación y a las labores intelectuales; como poeta impuso su libertad de expresar su sensibilidad; como monja declaró su capacidad de mujer pensante para estudiar teología y de hacer compatible su religiosidad con una vida creativa; sin embargo, como dramaturga hizo algo más que una transgresión, el escribir, montar y editar comedias seculares, una de las máximas transgresiones que pudo llevar a cabo una monja enclaustrada.»

15. El Auto, por cierto, dedicado a la condesa de Paredes y pensado para su representación en la Corte, según se indica en el frontispicio de la princeps, es posible que no llegara a escenificarse, aunque lo considera factible Enrique Marini Palmieri, "Notas a la "Loa" del Divino Narciso, auto sacramental de sor Juana Inés de la Cruz», Revista de Literatura, LXXI:141, 2009, pp. 207-232, quien, frente a estrategias preconcebidas, (se) propone «adoptar una lectura [...] isócrona» (p. 213) que le conduce «al sentido y a la realidad del nacer de una América, que es una y otra, doble y múltiple, unión y reunión en su eternidad y en su novedad. América nueva, ya en el siglo XVII. Nueva de un criollismo nuevo, que deletrea la singular identidad de las naciones que, dos siglos después, serán independientes en el damero hispanoamericano» (p. 229). 
el 25 de noviembre de 1690, en la que reconviene a Sor Juana Inés para que se dedique a las letras divinas y abandone las humanas. La Respuesta de la poetisa a la muy ilustre Sor Filotea de la Cruz está fechada el 1 de marzo de 1991; en ella, Sor Juana defiende su derecho (el derecho de una mujer) al estudio: «Bendito sea Dios - escribe- que quiso fuese hacia las letras y no hacia otro vicio, que fuera en mí casi insuperable» ${ }^{16}$; que Sor Juana sufrió presiones y hasta persecuciones por ello, resulta a estas alturas difícilmente cuestionable; una simple reflexión, extraída de la Respuesta y centrada en la poesía, puede servirnos de ejemplo:

Pues por la (en mí dos veces infeliz) habilidad de hacer versos, aunque fuesen sagrados, ¿qué pesadumbres no me han dado o cuáles no me han dejado de dar? Cierto, señora mía, que algunas veces me pongo a considerar que el que se señala, o le señala Dios que es quien sólo lo puede hacer, es recibido como enemigo común, porque parece a algunos que usurpa los aplausos que ellos merecen o que hace estanque de las admiraciones a que aspiraban, y así le persiguen ${ }^{17}$.

Como se deja entrever, la Respuesta a Sor Filotea nos descubre el posicionamiento de una mujer frente a las celadas que le $\operatorname{tienden}^{18}$ y la

16. Cito por Respuesta de la poetisa a la muy ilustre Sor Filotea de la Cruz, en Fama y obras póstumas del fénix de México, décima musa, poetisa americana, Sor Juana Inés de la Cruz, Madrid, por Manuel Ruiz de Murga, 1700, p. 26, modernizando la puntuación y las grafías

17. Respuesta, op. cit., p. 27; insiste en ello más adelante, p. 52: «Pues si vuelvo los ojos a la tan perseguida habilidad de hacer versos, que en mí es tan natural que aun me violento para que esta carta no lo sean, y pudiera decir aquello de Quidquid conabar dicere versus erat, viéndola condenar a tantos tanto y acriminar, he buscado muy de propósito cuál sea el daño que puedan tener, y no lo he hallado.»

18. Me limito a recoger otra declaración inequívoca contenida en la Respuesta, p. 54: «Pues si está mal el que los [versos] use una mujer, ya se ve cuántas los han usado loablemente; pues, ¿en qué está el serlo yo? Confieso desde luego mi ruindad y vileza; pero no juzgo que se habrá visto una copla mía indecente. Demás, que yo nunca he escrito cosa alguna por mi voluntad, sino por ruegos y preceptos ajenos, de tal manera que no me acuerdo haber escrito por mi gusto sino es un papelillo que llaman El Sueño.» A propósito de no haberse «visto una copla mía indecente», véase el capítulo dedicado a la cuestión por Margo Glantz, Sor Juana: la comparación y la hipérbole, México, Conaculta, 2000, pp. 229-244; asimismo, Pamela H. Long, «"Ruidos con la Inquisición”: los villancicos de Sor Juana», Destiempos, 14:1, 2008, pp. 566-578. Podrían citarse otros muchos ejemplos, incluso más contundentes, extraídos de la famosa Carta de Monterrey, dirigida al P. Núnez, o de la firmada por sor Serafina de Cristo; si me centro básicamente en la Respuesta, que tiene como referencia directa la Atenagórica (núcleo generatriz de todos los ruidos que planean sobre los silencios de sor Juana en su años finales), es por su incuestionable autoría y, al tiempo, por acogerme a seguro en tanto persista alguna sospecha sobre la autoría de la carta al P. Núñez o se cuestione al carácter autógrafo de la firmada por sor Serafina. 
voluntad de persistir en su actividad intelectual y creativa. La Atenagórica ha servido de pretexto a la Carta de Sor Filotea y ésta, en contrarréplica, estimula la Respuesta de Sor Juana. Son muchas las derivaciones que se implican en este triángulo que conforman el domumento hecho público sin autorización por el obispo de Puebla, la réplica de éste y la autodefensa de la autora; y los problemas se ramifican más aún si añadimos la Carta remitida al P. Núnez hacia 1682 y la escrita, firmada por Serafina de Cristo, un mes antes de la Respuesta, una y otra objeto de reticencias en lo que interesa a la autenticidad de la autoría ${ }^{19}$. Estos documentos, junto a nuevos hallazgos y novedosas revisiones críticas (de la poesía en general, de los villancicos en particular y de la producción dramática), son otras tantas piezas de un mosaico, con la Atenagórica como tesela angular, que cuanto más sistemáticamente ensambladas, más y mejor ayudarán a iluminar las circunstancias que planean sobre los años finales de la monja jerónima. Indica al respecto Sara Poot Herrera: «A partir de estos testimonios [encontrados en las últimas décadas en Portugal, en México, en los Estados Unidos y en España], los estudios sobre Sor Juana y su época cuestionarán y exigirán cada vez más lecturas basadas sobre todo en documentación histórica que es la que en los últimos tiempos, y como una nueva etapa de estudios sobre la Nueva España, proporciona bases más firmes para el análisis y la interpretación.» ${ }^{20}$ A todo ello hay que ańadir los personajes directa o indirectamente implicados

19. La autoría de la Carta al P. Antonio Núñez de Miranda, confesor de Sor Juana Inés, no ofrece dudas a Antonio Alatorre, "La carta de Sor Juana al P. Núnez (1682)", Nueva Revista de Filología Hispánica, 35: 2, 1987, pp. 591-673, y tampoco a Marie-Cécile Benassy-Berling, Humanismo y religión en Sor Juana Inés de la Cruz, México, UNAM, 1983. Sobre la carta firmada por Sor Serafina de la Cruz, véase Elías Trabulse, El enigma de Serafina de Cristo. Acerca de un manuscrito inédito de Sor Juana Inés de la Cruz (1691), Toluca, Instituto Mexiquense de Cultura, 1995, así como su estudio introductorio a la edición facsimilar de Sor Juana Inés de la Cruz, Carta de Serafina de Cristo. 1691, Toluca, Instituto Mexiquense de Cultura, 1996; Elías Trabulse asegura que dicha carta es un documento autógrafo de Sor Juana, lo que «deja estupefactos» a Antonio Alatorre y Martha Lilia Tenorio, Serafina y Sor Juana (con tres apéndices), México, El Colegio de México, 1998, p. 82; más recientemente, Antonio Alatorre, "Una Defensa del Padre Vieira y un Discurso en Defensa de sor Juana", Nueva Revista de Filología Hispánica, LIII:1, 2005, pp. 63-83. Entre los numerosos trabajos que abordan los años finales de Sor Juana, a la luz de novedosas revisiones críticas y de nuevos documentos, conviene recordar los volúmenes coordinados por Sara Poot Herrera (ed.), Sor Juana y su mundo. Una mirada actual, México, Universidad del Claustro de Sor Juana/FCE, 1995, y por Margo Glantz (ed.), Sor Juana Inés de la Cruz y su contemporáneos, México, UNAM, 1998, así como los once estudios coeditados por K. Josu Bijuesca y Pablo A. J. Brescia, Sor Juana \& Vieira: trescientos años después, Santa Barbara, University of California, 1998.

20. Sara Poot Herrera, «Sor Juana: nuevos hallazgos, viejas relaciones», Anales de Literatura Española, 13 (1999), p. 63. 
en los escritos y en la situación que vive Sor Juana, con el padre Vieira al fondo, el padre Palavicino en el transfondo y, más cercanos (también en el control celoso de la monja jerónima), el padre Núñez de Miranda, el obispo Fernández de Santa Cruz y el arzobispo Aguiar y Seijas ${ }^{21}$; añádanse otras amistades del jesuita confesor al servicio del Santo Oficio, sin olvidar el proceso inquisitorial en el que se la involucra y los votos de sangre a que es obligada como una prueba urdida para expandir la idea de una renuncia voluntaria a seguir escribiendo. Pero, a pesar de todos los inconvenientes, Sor Juana prosiguió con la escritura, como prueban los hallazgos que se han venido haciendo públicos; recordamos simplemente, a modo de ejemplo, los Enigmas ofrecidos a la discreta inteligencia de la soberana Asamblea de la casa del placer $^{22}$, proyecto de publicación animado por la Condesa de Paredes, que participa con un romance de 56 versos; el proyecto formaría parte de una estrategia diseńada por la la exvirreina de la Nueva Espańa, amiga de Sor Juana posicionada frontalmente contra las intenciones del arzobispo Francisco Aguiar y Seijas ${ }^{23}$. Es significativo que la Condesa de Paredes, que propició la edición de Inundación castálida, no reaparezca hasta el proyecto de publicación de los Enigmas y que, a pesar de su honda amistad con Sor Juana, no figure en la lista de personajes ilustres (muchos de ellos mujeres) ${ }^{24}$ que la elogian en la Fama, lo que se comprende si aceptamos, como indica

21. Entre los personajes que ejercieron mayor presión en sor Juana, Giuseppe Bellini, "Sátira y humor en sor Juana», en Ignacio Arellano y Antonio Lorente Medina (eds.), Poesía satírica y burlesca en la Hispanoamérica colonial, Madrid, Iberoamericana-Vervuert, 2009, pp. 41-42, menciona directamente el caso «de su confesor, el padre Antonio Núñez de Miranda, riguroso defensor de la moral, que sometió a la monja a rigores de los que sólo un carácter fuerte como el suyo pudo salvarse. Rigores que acentuó el maniático arzobispo de México, don Francisco de Aguiar y Seijas, enemigo, como el anterior, de las mujeres, que consideraba seres impuros».

22. Sor Juana Inés de la Cruz, Enigmas ofrecidos a La Casa del Placer, ed. Antonio Alatorre, México, El Colegio de México, 1994. Los Enigmas, dados a conocer en 1968 por Enrique Martínez López, fueron escritos en 1693 para las monjas en Portugal en una fase álgida del proceso abierto contra Sor Juana.

23. No está de más recordar, al respecto, lo que indica Giuseppe Bellini, «Sátira y humor en sor Juana», op. cit., p. 42: «La protección constante de la familia de los condes de Paredes, los virreyes, valió para defenderla durante todo el tiempo de su permanencia en México, pero cuando sus protectores regresaron a España, Sor Juana quedó sin defensa, y fueron los años más difíciles y amargos de su vida.»

24. Aunque se ha señalado que la condesa de Paredes podría ser la "gran señora muy discreta y apasionada de la poetisa» que remite a Castorena la décima acróstica incluida en la Fama, no lo cree así Georgina Sabat de Rivers, "Mujeres nobles en el entorno de Sor Juana", en Sara Poot Herrera (ed.), " $Y$ diversa de mi misma / entre vuestras plumas ando». Homenaje internacional a Sor Juana Inés de la Cruz, México, El Colegio de México, 1993, pp. 1-19. 
Elías Trabulse ${ }^{25}$, que dicha edición fue urdida por el arzobispo Aguiar y Seijas para difundir la idea de que Sor Juana había dejado de escribir voluntariamente. En medio de esa tormenta abiertamente desencadenada tras la publicación de Inundación, prolongada hasta su muerte y aún con el eco de los truenos en la Fama, se puede constatar (y acaso comprender) cómo ese sintagma -Inundación castálida- tan torrencialmente barroco se diluye en un generalista Poemas y se remansa en un aséptico Segundo volumen; cómo llama asimismo la atención que se hayan quitado en 1692 los laureles de la portada, refiriendo simplemente su condición de monja; que ya no se hagan indicaciones, pragmáticamente eficaces para el lector, como que la autora en varios metros, idiomas y estilos fertiliza varios asuntos con elegantes, sutiles, claros, ingeniosos y útiles versos para enseñanza, recreo y admiración, y que se hayan multiplicado de manera sorprendente los preliminares...

Precisamente algunos datos extraídos de los preliminares (entre otras muchas finezas que en ellos se infiltran) se antojan significativos. De 1689 a 1690, es decir, de la edición de Inundación castálida a la primera con el título de Poemas, se ha suprimido el parrafito siguiente en la aprobación de fray Luis Tineo: «Lo mismo [que de muy grandes Santos] digo de Soror Juana, y añado (porque, como decía el gran Cardenal Belarminio, tengo también mi poco de Profeta a lo viejo) que ha de ser muy santa, y muy perfecta, y que su mismo entendimiento ha de ser causa de que la celebremos por el San Agustín de las mujeres.» ${ }^{26} \mathrm{El}$ elogio, que debía rechinar hiperbólicamente en los oídos de sus detractores, acaso aconsejara la supresión para no atizar más el fuego que ya abrasaba a la monja jerónima, facilitar su trabajo y no obstaculizar la difusión de su obra y, al tiempo, para situarla como avis, incluso rara, pero in terris. En esta misma línea podría entenderse la incorporación, también a partir de la primera edición de Poemas (Madrid, 1690), del Prólogo al lector, escrito por la autora a petición de la condesa de Paredes en versos octosílabos condicionados por la "prisa de los traslados», pero redactados en medio de las presiones a que está siendo sometida y avisando «que, cuando los he hecho, / ha sido, en el corto espacio, / que serían al ocio las / precisiones de mi Estado: / Que tengo poca salud, / y continuos embarazos; / tales que, aun diciendo esto, / llevo la pluma trotando», según recogen la undécima y duodécima cuartetas del romance. El componente de captatio benevolentiae

25. Elías Trabulse, "El silencio final de Sor Juana”, en K. Josu Bijuesca y Pablo A. J. Brescia (eds.), Sor Juana \& Vieira, trescientos años después, op. cit., pp. 143-156.

26. Cito por Inundación castálida de la única poetisa, musa décima, soror Juana Inés de la Cruz, Madrid, Juan García Infanzón, 1989, p. 5v-6r, en Antonio Lorente (ed.), Textos clásicos de poesía virreinal, Madrid, Colección Clásicos Tavera, 2001 (CD-rom); modernizo la puntuación y las grafías. 
propio de la tópica prologal no neutraliza otras intenciones contextualmente implicadas, como tampoco las anula en la consideración que da sor Juana a esos «papelillos» (f. 3) ${ }^{27}$ que acaban conformando el Segundo volumen y que «llevan la disculpa de ser obra, no solo de una mujer, en quien es disculpable cualquier defecto, sino de quien [...] nunca ha sabido cómo suena la viva voz de los Maestros ni ha debido a los oídos, sino a los ojos las especies de la Doctrina en el mudo magisterio de los libros» (f. 4), como manifiesta, con disculpa que es a la vez autoafirmación, en su dedicatoria a don Juan de Orúe, mientras bracea animosa en un mar proceloso; y aguas removidas debía llevar el río para resonar a uno y otro lado del Atlántico, cuando en la primera de las censuras, tras considerar «que el mayor elogio de este segundo Tomo, que ahora se pretende imprimir, es el aplauso y estimación con que fue recibido y celebrado de todos el primero» (f. 5), el Padre Maestro Juan Navarro Vélez advierte: «En los versos pudiera reparar algún escrupuloso y juzgarlos menos proporcionado empleo de una Pluma Religiosa, pero sin razón; porque escribir versos fue galantería de algunas Plumas que hoy veneramos Canonizadas, y los versos de la Madre Juana son tan puros...» (f. 7), comentario, por cierto, similar a otros empleados por sor Juana en su Respuesta; incluso la calificación de los versos como «tan puros» reafirma el juicio de la autora de no haberse "visto una copla mía indecente». En fin, como si quiera asegurarse antes de «dar a la luz pública este segundo Volumen de las Obras de la Madre Juana Inés de la Cruz», don Juan de Orúe, «o por anticiparles el gusto de leerlas, o por examinar si corrían uniformes en aquel aplauso general con que fue recibido el primer Tomo, las consultó con algunos Varones insignes en Religión y Letras, remitiéndoselas para que las viesen» (f. 16 ${ }^{28}$. Vale que don Juan de Orúe quiera generosamente facilitar a esos varones insignes el gusto de la lectura anticipada; pero, más allá de arropar a sor Juana como su fama requiere, ¿cómo entender la curiosidad vertida en esa especie de sondeo sobre la uniformidad del aplauso?; ¿quiere comprobar si, como en el caso de Inundación castálida, la aceptación del Segundo volumen será unánime o, por el contrario, puede causar reticencias

27. Cito, modernizando la puntuación y las grafías, por Segundo volumen de las obras de soror Juana Inés de la Cruz, Sevilla, Tomás López de Haro, 1692 [Cervantes Virtual], indicando entre paréntesis el folio correspondiente.

28. En este marco, toscamente esbozado, adquiere pleno sentido la opinión de Georgina Sabat de Rivers, en introducción a Sor Juana Inés de la Cruz, Inundación castálida, Madrid, Castalia, 1982, p. 23: «En algún momento después de la publicación de Inundación castálida (1689), su confesor, el padre A. Núńez de Miranda, quien había guiado espiritualmente a sor Juana aun antes de entrar en el convento, le hizo sentir severamente su influencia para que abandonara la poesía que no se atuviera a rigurosos cánones de seriedad.» Esta opinión, como es sabido, no ha ido sino reforzándose desde que se realizó a nuestros días. 
a determinados sectores?; y, en caso de que las cause, ¿a qué pueden ser debidas? En este supuesto, habría que escrudriñar tales reticencias a la luz de las penosas circunstancias que rodean a la autora entre la publicación del primer tomo y el segundo; y, también en este sentido, habría que valorar la austera portada del Segundo volumen por contraste con la apoteosis que concentra la de Inundación castálida; ‘acaso, pensamos, una presentación más comedida no resultaba decorosamente más adecuada a la condición de monja de la autora y, al tiempo, más apropiada para apaciguar los ánimos de los sectores más reticentes en el ámbito de recepción? Difícilmente los cambios producidos de 1689 a 1690 y, sobre todo, a 1692 pueden pasar desapercibidos.

En 1670, muerta la causa, se atenúan los efectos por más que aún, como sugiere Elías Trabulse, se alargue la sombra de las aviesas intenciones del arzobispo Aguiar y Seijas (muerto dos años antes) en el transfondo de la edición de la Fama y obras póstumas, que tiene más de fama que de obras, pues solo recoge diez poemas de Sor Juana; se retoman los laureles: Fénix de México, Décima Musa, Poetisa americana, se dedica el volumen a la Majestad Católica de la Reina Nuestra Señora Doña Mariana de Neoburg, se coloca tras la portada un grabado cuya parte central está ocupada por el retrato de la autora enmarcado en un ramo de laurel entre dos columnas que representan a Europa y América sobre cuyos capiteles se alzan dos angelotes con la corona de la inmortalidad y la trompeta de la fama, respectivamente, junto a otra serie de motivos alegóricos... Se suceden páginas y páginas de preliminares, siguen la Carta de sor Filotea y la Respuesta de sor Juana junto a otros escritos de carácter devoto y, tras el breve paréntesis que acoge los poemas, coronan la obra composiciones que "lloran en todos los metros», como había avisado en el prólogo Juan Ignacio de Castorena, la muerte de la Décima Musa a lo largo de las 46 páginas finales.

Los paratextos, como ya se ha dicho, entreabren las puertas a la lectura del macrotexto. Por una parte, sugieren las tensiones contextuales entre el poder religioso, reticente a las actividades literarias e intelectuales de la monja, y el poder político, ejemplificado en el apoyo y mecenazgo de los distintos virreyes (recuérdese que es la Condesa de Paredes quien promueve la publicación de Inundación castálida y quien diseńa en apoyo de la monja la publicación de los Enigmas; y que, posicionada frontalmente ante la actitud del arzobispo Aguiar y Seijas, no figura en la lista de personajes ilustres que pregonan la Fama de Sor Juana); tensiones que se perciben incluso entre la severa actitud que se adopta en la colonia y la percepción de mayor simpatía que se muestra en la metrópoli ante el caso; actitud y percepción, por distintas y distantes, incluso dentro del mismo ámbito eclesial, recíproca y sutilmente 
matizadas cuando no claramente contrapuestas. Los paratextos, por otra parte, orientan sobre la estructura macrotextual. Se sabe, por declaraciones vertidas en la carta al P. Núñez y en la Respuesta, entre otros momentos, que el apego inquebrantable a la escritura es paralelo al desapego que muestra hacia sus versos; así se refleja en el prólogo a Inundación cuando el prologuista informa que la Condesa de Paredes, a punto de regresar a España, solicitó, «pedidos por curiosidad de buen gusto y mal unidos por desestima de la Madre Juana Inés, unos cuadernos que amagaban a libro, y a estos escribió el soneto, desimaginada de que sus trabajos fuesen de tanto peso que aun hiciesen sudar en España las prensas»; el soneto referido es el que dirige "A la Excelentísima Señora Condesa de Paredes, Marquesa de la Laguna, enviándole estos papeles, que su Excelencia, la pidió, y pudo recoger Soror Juana de muchas manos en que estaban, no menos divididos que escondidos, como tesoro, con otros que no cupo en el tiempo buscarlos ni copiarlos» ${ }^{29}$; y en la rúbrica que portica el Prólogo al lector, escrito en verso por la propia autora e incorporado a partir de la edición de Poemas, se advierte que «tenía tan negados Soror Juana sus versos como lo estaba ella a su custodia, pues en su poder apenas se halló borrador alguno» ${ }^{30}$. En fin, en la dedicatoria a Don Juan de Orúe, mecenas del Segundo volumen, se refiere a su obra, al modo de fray Luis de León, como «estos papelillos» y manifiesta su confianza de poder ofrecerle otras obras «si no más primorosas, no tan incultas.» (f. 4).

Cuadernos mal unidos que amagan a libro, papeles no menos divididos que escondidos, versos negados a la custodia... favorecían, en el trayecto de la autora a la edición, el resultado de la varietas como criterio de disposición, que es el predominante en los impresos del siglo XVII. Así, por lo demás, se anuncia desde la portada de Inundación castálida, donde se indica que la autora, en varios metros, idiomas y estilos, fertiliza varios asuntos con elegantes, sutiles, claros, ingeniosos, útiles versos para enseñanza, recreo y admiración. Desde luego, la ordenación no se atiene a criterios de tipo cronológico, temático, métrico o genérico, sino que recoge la obra, como reproduciendo la secuencia de hallazgo y recopilación, "al modo de una antología acumulativa», por decirlo con palabras de José Carlos González Boixo ${ }^{31}$; y

29. Inundación castálida de la única poetisa, op. cit., pp. XV y 1, respectivamente.

30. Cito, modernizando puntuación y grafías, por Poemas de la única poetisa americana, Musa décima, Soror Juana Inés de la Cruz, Madrid, Juan García Infanzón, 1690, p. 7v.

31. José Carlos González Boixo (ed.), introducción a Sor Juana Inés de la Cruz, Poesía lírica, Madrid, Cátedra, 1992, pág. 37. Al respecto, Felipe Pedraza, en la introducción a su Edición crítica de las "Rimas" de Lope de Vega, I, Universidad de Castilla-La Mancha, 1993, p. 21, indica que «los cancioneros renacentistas y barrocos se parecen más a antologías, donde el criterio de variedad tiene mayor peso que el de coherencia y unidad.», lo que corrobora 
así ocurre tanto en Inundación castálida como en el Segundo volumen, por más que en éste se conformen varios bloques presididos por denominaciones como Poesías lírico-sacras, Poesías cómico-sacras (en realidad, cuatro loas y tres autos), Poesía líricas (que se inician con el Primero sueño), Poesías cómicas (grupo que incluye loas, comedias y sainetes) y Más poesías lírico-sacras. Aun a grandes trazos, puede deducirse de lo expuesto que Sor Juana Inés de la Cruz en ningún momento se plantea un proyecto de edición, que en ningún momento pretende editar sus obras: se las editan; pero, en el proyecto de edición y en el trayecto de un libro a otro, los cambios paratextuales parecen sugerir (simplemente; no se lea, pues, más allá de lo que delimita la perífrasis) que también los libros fueron sufriendo las consecuencias de las presiones y las persecuciones que por esas fechas, contextualmente, padecía su autora y, acaso por ello, fueron adaptándose a las circunstancias.

Algo muy distinto es lo que, por esos años de la Inundación castálida, está urdiendo Juan del Valle y Caviedes en Lima: un libro manuscrito con los elementos preliminares del libro impreso que, por efectos de la subversión paródica de tales elementos, (no necesaria, pero sí) difícilmente podía acceder como tal al mercado. Valle y Caviedes se constituía en autor y autoridad que sancionaba su producto, sometido, a partir del manuscrito autógrafo, a la complicidad de la memoria, a las alteraciones de la recitación oral, a la pericia del copista, a las supresiones, adiciones, reelaboraciones, etc. Se conocen, hasta la fecha, diez manuscritos con las obras de Caviedes, secuenciados desde finales del siglo XVII (uno), a lo largo del siglo XVIII (siete) y en el XIX (dos), cuando Manuel de Odriozola imprime por vez primera su obra (1873), prologada por Ricardo Palma, con el título de Diente del Parnaso. Poesías serias y jocosas. Esta ramificación manuscrita refrenda en buena medida la exitosa y continuada difusión de la poesía de este jienense afincado en el Perú, su popularidad y su fama ${ }^{32}$. No se pretende aquí, pues no es esa la intención, poner de relieve las muchas aberraciones que los

el estudio de Valentín Núñez Rivera, "Los poemarios líricos en el Siglo de Oro: disposición y sentido", Philologia Hispalensis, 11, 1996-97, pp. 153-166. Véase asimismo Santiago Fernández Mosquera, “"El cancionero”: una estructura dispositiva para la lírica del Siglo de Oro», Bulletin Hispanique, 97, n 2, 1995, pp. 465-492.

32. Al referirse a los dos manuscritos conservados de Rosas de Oquedo, indica Pedro Lasarte, "Autoría y compilación poética virreinal, a fines del siglo XVI: caso Mateo Rosas de Oquendo", Calíope, 13: 1, 2007, pp. 66: «Que existan estos dos manuscritos con muchas variantes de la obra de Rosas y que ambos sean copias de otros pliegos o muscritos es muestra [...] de la evidencia de que la obra de Rosas de Oquendo gozaba de cierta popularidad.» Si trasladamos la reflexión a los manuscritos conservados de la obra de Valle y Caviedes, éste debió de gozar sin duda de una mayor popularidad, pues son más numerosas las copias que se conservan de su obra. 
manuscritos presentan ni abordar otras cuestiones que serían, en todo caso, objeto de una edición crítica ${ }^{33}$. El propósito es describir someramente cómo Valle y Caviedes diseńa el libro, manuscrito, las implicaciones que conlleva la modalidad paródica y los avatares consiguientes de su difusión.

Por el tipo de letra, de fines del siglo XVII, el manuscrito más antiguo es el de la Universidad de Yale (s. 158) ${ }^{34}$, con el nombre de Caviedes en el tejuelo y escrito en la portada: Diente del Parnaso, / que trata dibersas mate / rias contra Médicos, Ver / sos amorosos, a lo divino, / Pinturas y retratos. / Compuesto. / Por D. Juan Cabiedes / que escribió en / Lima / Año de 1689. Mientras que $\mathrm{Ma}^{\mathrm{a}}$. Leticia Cáceres no cree que el título fuera puesto por Caviedes, sino por el Dr. José M. Valdés, Abrines sostiene que Valle y Caviedes, que habría concluido su obra en 1691, solamente escribió Diente del Parnaso, omitiendo nombre y año, pues la fecha, 1689, choca con el epígrafe de uno de los poemas incluidos: Presentóse esta petición ante el señor don Juan Caviedes, juez pesquisidor de los errores médicos, en Lima a 9 de marzo de 1690, contra un médico... ${ }^{35}$; otros dos poemas están escritos con posterioridad a la fecha

33. Según Trinidad Barrera, "La obra de Juan del Valle y Caviedes", en Ignacio Arellano y Antonio Lorente Medina (eds.), op. cit., pp. 37-38, aún «queda mucho por hacer en este campo, pero mientras se acomete la edición crítica de la obra que podemos atribuirle, urge una edición con un texto razonado que reúna un buen ramillete de sus poemas más característicos que serían, a mi entender, los satírico-burlescos.» Daniel R. Reedy, que utiliza como base para su edición el manuscrito de la Universidad de Duke, sostiene en su introducción a Juan del Valle y Caviedes, Obra completa, Caracas, Ayacucho, 1984, p. XLI, que se conforman «tres familias distintas de manuscritos» a partir de un núcleo representativo de poesías que se va incrementando de manera ramificada, incluso en vida del autor. La edición de $M^{a}$. Leticia Cáceres no sigue un determinado manuscrito en su intento de conseguir un «texto concertado» que pretende ser el «corpus caviedano definitivo» y ofrecer «la versión más ajustada al pensamiento y creatividad del autor», como indica en su introducción a Juan del Valle y Caviedes, Obra completa, Lima, Banco de Crédito de Perú, 1990, p. 221. Luis GarcíaAbrines, en introducción a Juan del Valle y Caviedes, Diente del Parnaso, Jaén, Diputación Provincial, 1993, pp. 77-78, admite la existencia de un manuscrito autógrafo, perdido, que da lugar a cinco familias; por cierto, en su opinión, cuatro de los manuscritos son malos, tres muy malos y otros dos malísimos. Además de las conjeturas abiertas por estos editores, véase el estudio más cercano de Antonio Lorente Medina, "La transmisión textual de la poesía de Juan del Valle y Caviedes: bases para su estudio”, en C. Mata y M. Zugasti (eds.), Actas del Congreso "El Siglo de Oro en el nuevo milenio", Pamplona, Eunsa, 2005, vol. 2, pp. 1069-1088, y la propuesta más reciente de Carlos F. Cabanillas Cárdenas, "De nuevo sobre el corpus de poemas antigalénicos de Juan del Valle y Caviedes", en Ignacio Arellano y Antonio Lorente Medina (eds.), op. cit., pp. 59-75.

34. Según Luis García-Abrines, introducción a Diente del Parnaso, op. cit., pp. 80-81; sin embargo, para Daniel R. Reedy, en la «Noticia bibliográfica» a su edición, op. cit., p. XXXVIII, "parece ser de mediados del siglo XVIII".

35. Luis García-Abrines (ed.), Diente del Parnaso, op. cit., p. 125, n. 1. 
de recopilación indicada como las Décimas con estribillo... que aluden a la boda, en segundas nupcias, del doctor Melchor Vázquez, celebrada el 23 de agosto de 1693, o el Romance al doctor don Joseph de Fontidueñas..., fechado en 1696; por lo demás, entre las «diversas materias» que acoge, destaca la dirigida "contra médicos», que constituye per se un bloque homogéneo y compacto en torno al octosílabo, con predominio del romance, y animado por los tonos satíricos y burlescos. Este título, Diente del Parnaso, que se repite en otros dos manuscritos (el de la Biblioteca de la Universidad de Kentucky, de fines del siglo XVIII, y el de la Biblioteca Nacional del Perú, de fines del XIX, y posiblemente en el 8341 de la $\mathrm{BNM}^{36}$ ), sugiere ya una clara dirección de lectura: el libro es, en efecto, como un diente que muerde con sátira implacable y el autor, metaforizado como tal, se autoincluye en el selecto coro parnasiano.

Los tres manuscritos mencionados, así como el de la Biblioteca de la Universidad de Duke (de principos del XVIII) y el 17494 de la UNM (de fines del XVIII), reproducen en el frontispicio la sucesión de sintagmas Guerra fisica, proezas medicales, hazañas de la ignorancia, sacadas a la luz del conocimiento por un enfermo que milagrosamente escapó de los errores médicos por la protección del Señor San Roque abogado contra médicos, o contra la peste, que tanto monta. Dedicalas su autor a la Muerte, emperatriz de médicos, a cuyo augusto, pálido cetro feudan vidas y tributan saludes en el tesoro de muertos y enfermos. En la portada de estos dos manuscritos figuran títulos tan amplios y genéricos como Caviedes. Colección de sus poesias. Siglo XVII y Obras poéticas de Caviedes, respectivamente, lo que da cobertura a las diversas materias que acogen, siendo a su vez los que contienen un mayor número de poesías, aunque muchas no son de Caviedes. El manuscrito de la Biblioteca de los Padres Franciscanos de Ayacucho retoma en la portada, con variantes incluso en la ordenación, los sintagmas de los anteriores: Historia fatal, Asañas de la Ygnoracia, Guerra fisica, Proesas medicales, y estos dos últimos sintagmas son los que figuran en el tejuelo del manuscrito 8341 de la BNM, sin portada: Guerra física y Proesas medicales. Frente al carácter abierto a la diversidad temática y tonal de títulos como Caviedes. Colección de sus poesías u Obras poéticas de Caviedes, o frente al más restringido de Diente del Parnaso, pero no necesariamente limitado en sus dentelladas satíricas a la materia antigalénica, el de Guerra fisica, proezas medicales, hazañas de la ignorancia, repetido con algunas variantes en siete manuscritos, delimita el núcleo de poesías «contra

36. Id., p. 83, donde apunta: «El primer folio lleva el sello de la Biblioteca Nacional de Madrid en el recto, y en el verso la siguiente signatura: U. 319. Falta el siguiente folio con el título de la obra que, sin lugar a dudas, era Diente del Parnaso.» 
médicos», que sin duda resulta el bloque más homogéneo y característico de la producción caviedana por más que varios de los manuscritos así porticados ofrezcan muestras abundantes de "diversas materias». En cualquier caso, el carácter bélico de los sustantivos (guerra, proezas, hazańas) caracteriza hiperbólicamente la actividad médica, que la adjetivación acaba degradando por efectos de la parodia urdida; es una parodia clara del discurso heroico $y$, al proponerse el autor en la dedicatoria como "puntual coronista», lo es también de la historia o crónica oficial de la sociedad limeña a fines del siglo XVII. El tono así marcado por esa sucesión de sintagmas, desde la portada o el frontispicio, se proyecta en los demás elementos paratextuales, que caracterizan contiguamente el macrotexto, al que imponen sus marcas de ritmo, tono, estilo y modalidad, salvo en los casos en que lo jocoso cede ante lo serio; resultativamente, en su intencionalidad y su organización, el conjunto constituye una parodia del libro impreso ${ }^{37}$.

Valle y Caviedes, en efecto, diseña un libro con todos los elementos preliminares, obligatorios y potestativos, que son necesarios para que éste circule sin trabas; así, su libro tiene la correspondiente Aprobación, sancionada por la autoridad incontestable de San Agustín y, tras el elogio del autor al santo, refrendada por el Eclesiástico y reafirmada por la interrogación retórica del pecador. Tiene la prescriptiva $F e$ de erratas, con la que el libro «quedará fielmente impreso» $(3,22)^{38}$; está asimismo tasado «a cien simples adiciones / por cada uno de sus pliegos» (4, 3-4 ) y, con la Licencia del Ordinario -juez eclesiástico, pero también, por más «ordinario que el correo» $(5,2)$, de condición baja, vulgar y de poca estimación-, "licencia de imprimir damos» (5, 3); tampoco falta el Privilegio: «Tiene por toda su vida / el autor de este cuaderno / privilegio de imprimirlo» (6, 1-3); sigue la Dedicatoria al «Muy poderoso esqueleto» $(7,1)$, al que se pide, una vez «escrito este corto / cuerpo de libro que logra / título de cuerpo muerto» $(7,125-127)$, la protección correspondiente: "iAmparadlo! Y si algún tonto / censurare aquesta obra / dádmele con una albarda...» (7, 133-135). Tras la Dedicatoria

37. En este sentido, como señala Pedro Lasarte, Lima satirizada, op. cit., pp. 49-50, «es interesante notar que ambos autores [Oquendo y Caviedes] ostentan un deseo de enmarcar, o encuadernar sus obras manuscritas: un deseo de otorgarle a sus pliegos volátiles y transitorios un orden y organización asociados con la permanencia del tomo publicado o de la letra archivada, algo que, sugerimos, responde tanto a la parodia del libro como del archivo burocrático.»

38. Citaré en lo sucesivo por Juan del Valle y Caviedes, Diente del Parnaso, ed. Luis García-Abrines, op. cit., indicando entre paréntesis el número del poema y el verso o versos correspondientes. Para un acceso fácil a los dos manuscritos conservados en la BNM, véase Antonio Lorente Medina (ed.), Textos clásicos de poesía virreinal, Madrid, Colección Clásicos Tavera, 2001 [CD-rom]. 
se coloca, a modo de censura, el Parecer que dio de esta obra la Anotomía del Hospital de San Andrés: "Por comisión de un ingenio / aqueste tratado he visto / que pide mi parecer...» $(8,1-3)$. Y, para que no falte nada, se incluye el Prólogo al que leyere esta obra: «Señor lector o lectora ${ }^{39}$ : / el cielo santo permita / que encuentren este tratado / enfermos, por suerte mía» (9, 1-4), con la recomendación de que se ría de sí mismo en primer lugar, «de ellos» [los médicos] después y, finalmente, «Ríete de todo, puesto / que, aunque de todo te rías, / tienes razón. Dios te guarde, / sin médicos ni botica» $(9,129-$ 132).

No es difícil apreciar que Valle y Caviedes ha diseñado un libro con todos los elementos preliminares que demanda la impresión; pero, a pesar de autoconcederse la «licencia de imprimir» y el "privilegio de imprimirlo", sabe irónicamente que su proyecto no pasa de ser un «cuerpo de libro que logra / título de cuerpo muerto» en tanto que libro impreso, de ahí que se complazca en la parodia de esos elementos que arropan el libro de curso legal. A propósito de la parodia urdida, vale recordar a Bajtin cuando indica que «Los géneros paródicos [...] no pertenecen a aquellos géneros que parodian $»^{40}$; por contigüidad, bien puede decirse que unos preliminares subversivos que parodian los preliminares exigibles para la impresión, no pueden inscribirse en el ámbito institucional de los paratextos legales; por lo mismo, el texto al que cotextualmente preceden tampoco puede participar de las prerrogativas propias de la práctica institucionalizada ni planificarse consiguientemente para su difusión en ese ámbito. La sátira directa y mordaz, que apunta desde la portada "contra médicos» sin perder de vista esa diana en los preliminares, se antoja, junto a otros aspectos (léxico, fraseología...), motivo consistente para que así fuera ${ }^{41}$. Al no poder acceder a ese ámbito

39. Apréciese, por cierto, trasladando anacrónicamente el imaginario colectivo de nuestra época, la (que hoy llamaríamos) conciencia de género que tiene Caviedes al dirigirse igualitariamente a lector o lectora, posición que reitera en la composición en que parodia un edicto: «Nos y nosas, machos y hembras, / las vecinas y vecinos...» (30, 1-2).

40. Mijail M. Bajtin, Teoría y estética de la novela. Madrid, Taurus, 1989, p. 427.

41. En este sentido señala Daniel R. Reedy, en la «Nota bibliográfica» de su edición, op. cit., p. XXXVI: «Hemos de suponer que los manuscritos de la obra de Caviedes circulaban de mano en mano a finales del siglo XVII, quizá en forma clandestina debido a la acerba naturaleza de su sátira.» A propósito de la sátira, véase Pedro Lasarte, Lima satirizada (15981698): Mateo Rosas de Oquendo y Juan del Valle y Caviedes, Pontificia Universidad Católica del Perú, 2006, así como «El retrato satírico burlesco en la poesía de Juan del Valle y Caviedes y algunos diálogos literarios con Quevedo», en Ignacio Arellano y Antonio Lorente Medina (eds.), op. cit., pp. 227-238. Han centrado su atención en la sátira contra los médicos, entre otros, R. John Mccaw, «Playing Doctor: Satire, Lauthter and Spiritual Transformation in Valle y Caviedes's Diente del Parnaso», Caliope, 3:2, 1997, pp. 86-99, y Antony Higgins, 
institucionalizado, hay que buscar alternativamente otros circuitos paralelos de circulación en cuanto práctica social discursiva distante y distanciada de la legalidad vigente. Permítasenos, aunque sea a grandes trazos, decir algo al respecto.

Como indica Pedro Lasarte, siguiendo a Alejandro Hopkin y a Lorente Medina, Valle y Caviedes "mostraría la intención de elaborar la sátira de la medicina peruana como una suerte de parodia del discurso heroico tradicional” ${ }^{42}$ y los héroes, por inversión paródica, serían la muerte, los médicos que matan, los boticarios como cómplices y los malos poetas, prioritaria pero no exclusivamente. El caso es que no se trata de una sátira contra profesiones o tipos, sino que dispara contra personas concretas: Francisco Ramírez, Francisco Bermejo, Bartolomé Torres, Francisco Vargas Machuca, Miguel de las Heras..., médicos todos ellos, junto a otros de inferior categoría, con cargos relevantes ${ }^{43}$; el propio virrey, incluso, no se libra de alguna que otra dentellada (véase el Memorial que le da la Muerte al Virrey en tiempo en que se arbitraba si se enviarian navios con gente para pelear

"No Laughing Matter: Norm and Transgression in the Satirical Poetry of Juan del Valle y Caviedes", Bulletin of Hispanic Studies, LXXVI, 1999, pp. 109-120.

42. Pedro Lasarte, Lima satirizada (1598-1698), op. cit., p. 70. Ya Eduardo Hopkins, "El desengaño en la poesía de Juan del Valle y Caviedes", Revista de Crítica Literaria Latinoamericana, 2, 1975, p. 10, había llamado la atención sobre "las intenciones "épicas" de Caviedes», apoyadas en la inversión paródica de los héroes (la muerte, los médicos, los boticarios...); sobre el sometimiento a burlas carnavalescas de fábulas mitológicas y bailes teatralizados, ha escrito Eduardo Hopkins "Carnavalización de mitos clásicos en la poesía de Juan del Valle y Caviedes», en Teodoro Hampe Martínez (comp.), La tradición clásica en el Perú virreinal, Lima, UNMSM, 1999, pp. 173-190. Más esclarecedor, en el sentido que nos ocupa, es el artículo de Antonio Lorente Medina, «La parodia de los preliminares en la obra poética de Juan del Valle y Caviedes", Anales de literatura hispanoamericana, 21, 1992, pp. 297-307. Véase asimismo Antony Higgins, «Subject and Carnivalesque in Colonial Satire: A Study of Juan del Valle y Caviedes's "Coloquio entre una vieja y Periquillo a una procesión celebrada en esta ciudad"”, Calíope, 3:2, 1997, pp. 72-85, y Pedro Lasarte, "Juan del Valle y Caviedes como lector de Quevedo", La Perinola, 13, 2009, pp. 79-88.

43. En efecto, a modo de ejemplo, Francisco Ramírez Pacheco fue médico titular del Tribunal del Santo Oficio y Decano de la Facultad de Medicina de la Universidad de San Marcos; Francisco Bermejo y Roldán, además de Rector de la Universidad de San Marcos, ejerció como médico de cámara del virrey D. Melchor Liñán y Cisneros, arzobispo de Lima, fue también protomédico y llegó a ser Presidente del Real Protomedicato; Bartolomé de Torres ocupó los cargos de médico del Tribunal del Santo Oficio y protomédico de Tierra Firme; Miguel de las Heras, cuñado de Francisco Bermejo, fue también catedrático; como asimismo lo fue, además de protomédico, Francisco del Barco; Francisco de Vargas Machuca ejerció como médico de cabecera del arzobispo virrey y como catedrático de Vísperas de Medicina, cargo que compatibiliza con el protomedicato; en fin, Juan Isidoro Romero fue médico de cabecera del conde de Castelar. 
con el enemigo o si se haría muralla para guardar esta ciudad de Lima, 24). Es significativo que el Mercurio Peruano, que comienza a fines del XVIII a publicar algunas composiciones de Caviedes, al imprimir el 5 de julio de 1792 las décimas tituladas Coloquio que tuvo con la muerte un médico estando enfermo de riesgo, ańada la siguiente aclaración:

Los patriotas inteligentes y curiosos que reserven en su poder los ejemplares manuscritos de este Poeta, reconocerán en las presentes Décimas y en otros rasgos del mismo que sucesivamente se fueren publicando, algunas inversiones hechas con los nombres de personas muy conocidas en aquellos tiempos. La Sociedad, procediendo con la moderación que acostumbra, ha querido suprimirlos, pareciéndole que de este modo evitarán las quejas, que aun en el día pudieran suscitarse en vista de aquellas sátiras personales; no obstante ser dirigidas a sugetos que ya no existen, y escritas en la remota antigüedad de más de un siglo ${ }^{44}$.

Si un siglo después de muerto su autor, las sátiras de Caviedes aún seguían abriendo heridas, cuántas no causarían en su tiempo. Con estos precedentes, el camino para la impresión se antoja complicado cuando no en buena medida vetado, porque las personas atacadas, si no detentadoras del poder, estaban muy próximas a él. En estas circunstancias, la sátira se alía con la parodia, asociando el discurso poético con el discurso épico (Guerra física, proezas medicales, hazañas de la ignorancia) y con la crónica oficial, pues también el autor se propone «ser puntual coronista / de sus [los médicos] criminales obras» $(7,123-124)$, diseccionando, a la manera del Parecer que da la Anatomía, el campo de batalla. Bien se podría decir que Caviedes, utilizando el comentario de Rodríguez de la Flor, muestra «la capacidad manifiesta de un sistema expresivo para marchar en la dirección contraria a cualquier fin establecido, y su habilidad para deconstruir y percutir, en primer lugar, aquello que podemos pensar son los intereses de clase, que al cabo lo gobiernan y a los que que paradójicamente se sujeta, proclamando una adhesión dúplice» ${ }^{45}$. El marchar en dirección contraria a lo establecido con

44. Apud Luis García-Abrines (ed.), Diente del Parnaso, op. cit., p. 156, n. 1. Conviene matizar, no obstante, "que en la época la sátira y la vituperación cómica, aun de personajes conocidos, no eran juzgadas con la gravedad de nuestros días», como puntualiza Pedro Lasarte, Lima satirizada, op. cit., p. 31.

45. Fernando Rodríguez de la Flor, Barroco: representación e ideología en el mundo hispánico (1580-1680), Madrid, Cátedra, 2002, p. 19. Desde otro ángulo, en la intersección de referentes inmediatos y modelos escriturales, Mabel Moraña, Viaje al silencio: exploraciones del discurso barroco, México, UNAM, 1998, p. 14, entiende que la cultura barroca debe ser vista «como un paradigma dinámico y mutante, permeable no solo a los influjos que incorpora la 
un sistema expresivo que reconstruye y pervierte el sistema oficial, conlleva al menos dos consecuencias: una textual y otra, al tiempo, extratextual, la del libro y su difusión.

Al volver la espalda al ámbito social y legalmente institucionalizado, la subversión paródica de los preliminares priva a estos de cualquier valor institucional de manera que, autoanulados como elementos cotextuales para validar la impresión, asumen textualmente su función literaria, integrándose de manera orgánica en el macrotexto al que trasladan, por contigüidad, sus marcas distintivas: el octosílabo y el romance, versus formas y géneros humanísticos y renacentistas, como metro y cauce estrófico y privilegiados, la materia objeto prioritario de la sátira, la parodia con los efectos de la inversión y las derivaciones irónicas y humorísticas, junto a la perversión de prácticas sociales discursivas como el vejamen (18), el memorial $(24,27)$, el edicto (30), la receta (38), los procesos judiciales $(41,42,43)$, el examen universitario (50)..., "prácticas escriturales asociadas al ámbito culto de lo oficial y burocrático» ${ }^{46}$; con respecto a una de estas prácticas, señala Pedro Lasarte: «Las burlas ironizan la importancia del memorial, entregándolo en un lenguaje callejero y popular que invierte su carácter letrado» ${ }^{47}$. La cita, oportuna, sintética y prolépticamente, facilita la transición a la consecuencia extratextual antes referida, es decir, al ámbito de difusión. Distingue Ángel Rama, en la tipología de ciudades, la ciudad bastión, la ciudad puerto, la ciudad pionera de las fronteras civilizadoras y, sobre todo, la ciudad administrativa, que fue la que fijó la norma de la ciudad letrada; pero, como oportunamente advierte, "dentro de ellas siempre hubo otra ciudad, no menos amurallada ni menos sino más agresiva y redentorista, que la rigió y condujo. Es la que creo que debemos llamar ciudad letrada» ${ }^{48}$. Esta ciudad, según Ángel Rama

materialidad americana sino vulnerable también a los afectos de las prácticas de apropiación y producción cultural del letrado criollo, que redefine el alcance y funcionalidad de los modelos recibidos de acuerdo con sus propias urgencias y conflictos.»

46. Pedro Lasarte, Lima satirizada..., op. cit., p. 68. Como bien precisa P. Lasarte, «tales parodias adquieren un sentido especial ya que se encaran con el ejercicio de una burocracia que se percibía como cada vez más problemática y poco viable para el habitante del virreinato». (p. 48), lo que implica «la contradicción entre un poeta subversivo del poder oficial y otro defensor de él.» (p. 72).

47. Id., p. 87. A propósito de esa función de ironizar, viene a cuento insistir en lo que indica Wayne C. Booth, Retórica de la ironía, Madrid, Taurus, 1986, p. 13: «La ironía se contempla como algo que socava claridades, abre vistas en las que reina el caos y, o bien libera mediante la destrucción de todo dogma o destruye por el procedimiento de hacer patente el ineludible cáncer de la negación que subyace en el fondo de toda afirmación.»

48. Ángel Rama, La ciudad letrada, Hanover, Ediciones el Norte, 1984, p. 25; esta ciudad letrada, según Ángel Rama, «se distingue porque aspira a la unívoca fijeza semántica y 
precisa, «componía el anillo protector del poder y el ejecutor de sus órdenes: Una pléyade de religiosos, administradores, educadores, profesionales, escritores y múltiples servidores intelectuales, todos esos que manejaban la pluma, estaban estrechamente asociados a las funciones del poder... ${ }^{49}$. En esta asociación con el poder, esta ciudad letrada-escrituraria instituye y progresivamente consolida la palabra rígida, la lengua secreta, el lenguaje técnico y oscurantista... sobre unos principios fijos de la estética.

Ahora bien, en paralelo a esta ciudad letrada y en sus márgenes, comienza a gestarse la que, a medida que avanza el siglo XVIII y sobre todo a comienzos del XIX con Fernández de Lizardi, será una ciudad de base implícitamente burguesa que empieza a subvertir y pervertir las prácticas escriturales, tan rígidas y estereotipadas como (y por ello) enquistadas en la estructura del poder, marcando las distancias mediante la palabra fluida de la calle, el léxico coloquial, la fraseología e imaginaría de la plaza pública, es decir, los rasgos de la cultura oral ajenos a los circuitos letrados. Y es en esta ciudad, paralela a la ciudad letrada, donde encuentra Valle y Caviedes la viveza expresiva y rítmica que infiltra a sus modelos literarios, y donde tendrá, recíprocamente, su más amplio ámbito de difusión; una difusión, por marginal al anillo protector del poder, marginada de salida al manuscrito y sometida a las peripecias cambiantes de la tradición manuscrita. Pero diez manuscritos (con la dirección de lectura que implica la parodia de los preliminares), regularmente secuenciados en el tiempo, además de ratificar la persistencia de la difusión de la obra caviedana, parecen de algún modo comprometer el orden y fijeza de los signos que la ciudad letrada pretende conservar; incluso la escasa calidad de los manuscritos orienta a ese ámbito extramuros de la ciudad letrada; el simple cotejo de uno de los manuscritos, el 13494 de la BNM, acaso el más limpio y legible, con el de Flor de Academias, elaborado a la largo de las veintidós sesiones que se celebraron en «el Real Palacio desta Corte de Lima", en el gabinete del Marqués de Castell dos Rius entre el 23 de septiembre de 1709 y el 7 de abril de 1710, resulta suficientemente esclarecedor. Este manuscrito, por cierto, concluyó con la muerte de su mecenas; pero la dedicatoria inicial, la portada, otras dos dedicatorias y la

acompaña la exclusiva letrada con la exclusiva de sus canales de circulación.» (p. 55); aunque esta caracterización la refiere a la segunda mitad del siglo XX, en buena medida se acomoda, salvando el anacronismo, a la época que nos ocupa.

49. Ibid. En este marco, como oportunamente ha señalado Pedro Lasarte, Lima satirizada, op. cit., p. 51, "Valle y Caviedes, aunque sí recurre a la oralidad, esta recibe menos atención que la crítica de prácticas escriturales mucho más cercanas a la actividad burocrática o cortesana, como son las parodias de, entre otras, academias, memoriales, vejámenes o procesos judiciales.» 
Noticia proemial orientan, de haber sobrevivido el Marqués, a la impresión. El destino quiso que, en 1899 (casi dos siglos después), Ricardo Palma uniera en la misma edición esta Flor de Academias y el Diente del Parnaso en diálogo donde polemizan pragmática, lingüística y literariamente lo culto y lo popular.

Como se puede apreciar, a modo ya de conclusión, los siete libros sucintamente presentados, circunscritos al ámbito de la poesía novohispana entre 1675 y 1710 , tienen una historia diferente con rasgos propios que la singularizan. Con menos o más dificultades, el Ramillete de Evia, el Triunfo Parténico de Sigüenza y la poesía de sor Juana Inés (Inundación, Segundo Volumen y Fama) fueron publicados en la época acotada con intenciones diversas, en circunstancias distintas y con una proyección muy desigual en el espacio y en el tiempo. Si cabe, con un contraste aún mayor en su concepción, su materialización y su proyección, la poesía de Valle y Caviedes (que se autoconcede paródicamente la «licencia de imprimir» a la vez que parodia el libro impreso) y la recogida en la Flor de Academias no pasaron de la forma manuscrita a la impresión hasta casi dos siglos más tarde. En cualquier caso, libros todos ellos, representativos en su propia singularidad de la poesía novohispana, ofrecen avatares distintos - con indudable repercusión y sentido en el caso de sor Juana y de Caviedes ${ }^{50}$ - desde el proceso mismo de su conformación y en el trayecto, por canales diferentes, de su difusión impresa o manuscrita.

50. Vale recoger en este cierre (que lo es sólo del trabajo y no de los aspectos más problemáticos que en él se suscitan) la reflexión de Giuseppe Bellini, «Caviedes y sor Juana», en Jordi Aladro-Font (ed.), Homenaje a Don Luis Monguió, Newark, Delaware, Juan de la Cuesta, 1997, pp. 63-69 [Cervantes Virtual]: «La Colonia, a través de estos dos personajes, muestra ya su íntima decadencia. El drama personal de Sor Juana recibe tanta resonancia a través de la Respuesta a Sor Filotea, que se transforma en drama de todo el Virreinato de la Nueva España. Y Caviedes, en toda su obra satírica no hace más que denunciar el desastre, que es un desastre humano, moral esencialmente. El aislamiento de la monja de México, su silencio final, denuncian más que otras formas de protesta el momento crítico de un mundo fundado sobre un principio de autoridad del todo injusto. Con la resonancia de su voz, bien metido dentro de la sociedad, Juan del Valle y Caviedes muestra el desastre del Virreinato del Perú. Ambos testimonios de una época a la que, en forma distinta, pero directa, han participado.» Testimonio puntual de ello dan sus libros. 